\title{
AN EFFICACY COMPARISON STUDY BETWEEN TOPICAL ANTI ALLERGIC DRUGS IN PATIENTS WITH ALLERGIC CONJUNCTIVITIS IN WESTERN RAJASTHAN
}

KEY WORDS:

\section{Dr Pushpendra} Chotiya *

\section{Dr Arvind Chauhan}

MBBS,MS Opthalmology SR Dept of Ophthalmology Dr S N Medical College Jodhpur. *Corresponding Author

HOD and senior professor Dept of Ophthalmology Dr S N Medical College Jodhpur

\begin{abstract}
至
Backgroud : Allergic conjunctivitis is disturbing condition for patients and challenging condition for treating ophthalmologist and with increasing environmental pollution, the incidence of allergic conjunctivitis is increasing Severe disease requires steroid but milder form can be treated with newer topical anti allergic medication (combined anti-histaminic and mast cell stabilization function).Aim: In this study we compare efficacy of olopatadine (0.2\%), bepotastine $(1.5 \%)$, and alcaftadine $(0.25 \%)$ in treatment of allergic conjunctivitis .Methods: In this randomized, double blind clinical trial 60 allergic conjunctivitis patients divided in three groups. Relief of symptoms and signs were noted and compared. Results: There was no statistical significant difference found in terms of efficacy of all three drugs in resolving symptoms of allergic conjunctivitis, .There is almost complete relief after 1 week of use of medication $(\mathrm{P}<$ $0.001)$.
\end{abstract}

Introduction: Ocular allergy represents one of the most common conditions encountered by allergists and ophthalmologists The incidence and prevalence of allergic diseases has increased in the last few decades and allergic conjunctivitis has emerged as a significant problem Chief complains are itching, watering and redness. Symptoms are aggravated by exposure to dry and windy climates.$^{1-6,8}$ if severe symptoms left untreated or treated poorly leads to complication. Common complications include dry eye, infection and corneal scar decreased quality of life,vision threatening problems like limbal stem cell deficiency (LSCD) and secondary keratoconus due to rubbing of the eyes. ${ }^{7}$

Table 1: Disorders of allergic conjunctivitis 8

\begin{tabular}{|l|l|l|}
\hline Mild allergic conjunctivitis & Severe allergic conjunctivitis & Chronic microtrauma related disorders \\
\hline
\end{tabular} \begin{tabular}{|l|l|l} 
Seasonal conjunctivitis (SAC) & Vernal keratoconjunctivitis (VKC) & Contact lens induced papillaryconjunctivitis (CLPC)
\end{tabular} \begin{tabular}{|l|l|l|}
\hline Perennial conjunctivitis (PAC) & Atopic keratoconjunctivitis (AKC) & Giant papillary conjunctivitis (GPC)
\end{tabular}

Table 2 : Classification of allergic conjunctivitis ${ }^{9}$

\begin{tabular}{|l|l|l|l|l|}
\hline & Mild & Moderate & Severe & Blinding \\
\hline Bulbar Conjunctiva & Congestion & Congestion & $\begin{array}{l}\text { Thickening and Trantas } \\
\text { spots }\end{array}$ & Granulomas \\
\hline Tarsal Conjunctiva & Micro papillae & Macro (lmm) papillae & Giant (>lmm) papillae & Mega Cobblestones \\
\hline Cornea & - & Micro erosions & Macroerosions & Shield ulcer \\
\hline Limbus & - & $\begin{array}{l}\text { Focal }(<180) \text { degrees } \\
\text { inflammation }\end{array}$ & $\begin{array}{l}\text { Diffuse (>180) degrees } \\
\text { inflammation }\end{array}$ & Limbal deficiency \\
\hline
\end{tabular}

Table 3 : Treatment in Allergic Conjunctivitis ${ }^{10}$

\begin{tabular}{|l|l|l|}
\hline Nonpharmacologic & \multicolumn{2}{l|}{ Avoid allergens, Cold compresses, Lubricants } \\
\hline Pharmacologic & Antihistamines & Antazoline,emedastine,levocabastine, pheniramine \\
\hline Ocular topical & Vasoconstrictors & Naphazoline, oxymetazoline, phenylephrine, tetrahydrozoline \\
\hline & Mast cell stabilizers & Nedocromil,lodoxamide,sodiumcromoglycate, spaglumic acid \\
\hline & NSAIDs & Flurbiprofen, ketorolac \\
\hline & Dual action agents & Azelastine, epinastine, ketotifen, olopatadine \\
\hline & Corticosteroids & $\begin{array}{l}\text { Betamethasone, dexamethasone, fluorometholone, } \\
\text { loteprednol, medrysone, prednisolone, rimexolone }\end{array}$ \\
\hline Oral & Antihistamines & $\begin{array}{l}\text { Bilastine, cetirizine, desloratadine, ebastine, fexofenadine, } \\
\text { levocetirizine, loratadine, mizolastine, rupatadine }\end{array}$ \\
\hline Nasal topical & Corticosteroids & Fluticasone, mometasone \\
\hline
\end{tabular}

Recently, introduced FDA approved topical agents (such as olopatadine, bepotastine, and alcaftadine) have both anti-histaminic and mast cell stabilization action. ${ }^{[13]}$ These drugs not only control acute symptoms but also prevent relapses. The price range for these three molecules in India for every $5 \mathrm{ml}$ is $100,200,400$ Rs respectively. Every year, millions of outpatient clinic visits in the India are due to allergic conjunctivitis. The treatment of this condition put a huge burden on health system, can be reduced if we found most effective drug.
Most of the earlier studies comparing the efficacy of class of anti-allergic medications were according to conjunctival allergen challenge. ${ }^{[14-19]}$ There is not much literature available comparing the efficacy of these dual acting agents directly. One similar efficacy study done in tamilnadu south india but different demographic characteristics, made the conclusions ambiguous in our area. ${ }^{[9]}$ The results will provide quantitative information about highest efficacy drug and its possible implication on cost of treatment of allergic conjunctivitis. 


\section{Method :}

We conduct interventional, randomized, double blind, single centric clinical trial . 60 patients (age group $10-40$ years) with signs and symptoms of allergic conjunctivitis came to department of ophthalmology $\operatorname{Dr} \mathrm{S} \mathrm{N}$ Medical college a tertiary care center in Western Rajasthan for treatment were included.

The protocol was registered with the Ethics Committee.

\section{Inclusion criteria}

1. willing to participate in the study

2. no significant other illness

3. mild to moderate allergic conjunctival disease

4. no known hypersensitivity to either agent

\section{Exclusion criteria}

1. Need for topical steroids or topical immunosuppressive

2. Contact lens wearers

3. Concurrent ocular diseases such as dry eye

4. Planning to undergo ocular surgery during study period

5. History of alcohol or drug abuse

6. Positive history of an ocular herpetic infection, an active ocular infection

7 Actively taking systemic steroids or antihistamines within 7 days prior to enrolment.

8. Pregnant, planning to become pregnant, or nursing/ lactating

9. Use of any other topical ocular medications.

Written informed consent was taken. Patient's medical history was taken. The clinical examination was done for sixty patient patients and filled a performa having questionnaire grading their symptoms and the signs were evaluated by a masked investigator then each patient was allocated a number.

For uniform grading of symptoms and signs at each visit, we used scoring scales

\section{Symptom scoring:}

Itch scale (0-3): $0=$ no itch, $3=$ constant desire to itch.

Ocular redness and discharge scale (0-4):

$0=$ no redness or no discharge $4=$ severe redness or copious discharge.

Foreign body sensation and watering scale (0-3):

$0=$ absent symptoms $3=$ severe foreign body sensation or constant epiphora.

\section{Signs scoring:}

Upper tarsal papillae scale (0-3): $0=$ no papillae, $3=$ predominance of giant papillae.

Limbal activity scale $(0-3): 0=$ no limbal activity, $3=$ Horner Tranta dots. ${ }^{[17]}$

The study group was divided into three groups 20 in each by masked examiner using a random number table.

The groups were:

Group 1:Topical 0.2\% Olopatadine eyedrops BID

Group 2:Topical 1.5\% Bepotastine eyedrops BID

Group 3:Topical 0.25\% Alcafatadine eyedrops BID

Before starting treatment, performa used for recording symptoms and signs of patients. The instillation of the first eyedrop of anti-allergic medication was done in the outpatient department, and the patient was asked to fill the same questionnaire after $15 \mathrm{~min}$ and telephonically on the next day. Patients were reviewed at 1 week and $l$ month.

Patients were instructed to use gentle eyelid closure for at least 2 min after dosing, and to repeat instillation of a single drop, if there was uncertainty as to whether successful instillation of the treatment had occurred.

Masked investigator assessed signs, and patient completed the questionnaire form at review visits.

Data analysis was done using Microsoft excel and Epiinfo version 7.2.1.0. Descriptive data were presented as mean and SD (for quantitative data) and frequency and proportions (for qualitative data). Tests of significance included ANOVA for quantitative data and Chi-squared for qualitative data. All $P$ values were two-tailed at a significance level of 0.05 . Intention to treat analysis was done in this trial.

\section{Results}

We did not have any study drop out as all the patients came for follow-up visits. Age and gender distribution of patients in three groups is shown in Table 1. Mean time for the beginning of relief of itching was comparable in three groups with no statistically significant difference $(P>0.05)$. All three medications showed statistically significant relief in itching, with effect starting in minutes and complete relief of itching at l-week follow-up. [Shown in Table 2 and Figurel ] After 15 min of instillation of eyedrop, patients in all three groups had either no or minimal itching (itch score of 0 or 1), illustrating quick onset of action of all three medications. All three medications helped in relief of other symptoms such as redness, watering, discharge, and foreign body sensation with complete symptomatic relief in 1 week time [Table 2]. None of the patients needed topical steroid for worsening symptoms. All three medications were well-tolerated except for mild burning sensation noticed by a few patients, which was transient in nature.

As our cases does not have severe allergic conjunctivitis so severe upper tarsal papillae or Horner Tranta dots were not noted in the study group.

Table 1: Age and gender distribution of study subjects

\begin{tabular}{|c|c|c|c|c|}
\hline Age (years) & Group 1 & Group 2 & Group 3 & P value \\
\hline $10-20$ years & $4(\%)$ & $5(\%)$ & $6(\%)$ & 0.964 \\
$20-30$ years & $10(\%)$ & $9(\%)$ & $9(\%)$ & \\
$30-40$ years & $6(\%)$ & $6(\%)$ & $5(\%)$ & \\
\hline Gender & & & & \multirow{2}{*}{0.762} \\
\cline { 1 - 4 } Male & 12 & 10 & 12 & \\
Female & 8 & 10 & 8 & \\
\hline
\end{tabular}

Table 2: Comparison of itch score among study subjects

\begin{tabular}{|c|c|c|c|c|}
\hline Time & Group 1 & Group 2 & Group 3 & P value \\
\hline At presentation & $2 \pm 0.65$ & $2 \pm 0.65$ & $2 \pm 0.73$ & 1.000 \\
\hline 15 min & $0.6 \pm 0.5^{*}$ & $0.7 \pm 0.47$ & $0.7 \pm 0.47$ & 0.751 \\
\hline l day & $0.3 \pm 0.47^{*}$ & $0.4 \pm 0.5$ & $0.4 \pm 0.51$ & 0.760 \\
\hline 1 week & $0^{*}$ & $0^{*}$ & $0^{*}$ & \\
\hline P value & $<0.001(\mathrm{~S})$ & $<0.001(\mathrm{~S})$ & $<0.001(\mathrm{~S})$ & \\
\hline
\end{tabular}

Figure 1: line diagram showing distribution of itch score of patients in three groups at various time intervals

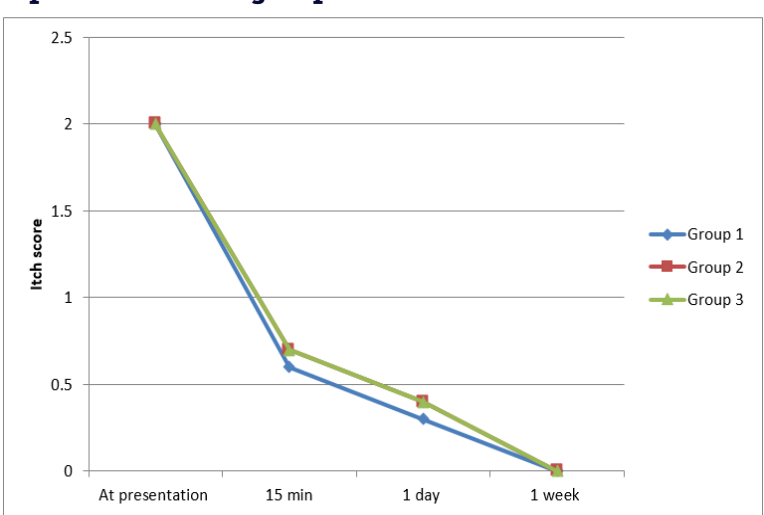

\section{DISCUSSION}

All three medications showed significant relief in symptoms of redness and itching, which was proved statistically effect 
starting within minutes of instillation of eyedrops.. Among $0.25 \%$ alcaftadine and $0.2 \%$ olopatadine in a study using conjunctival allergan challenge, alcaftadine was found superior to olopatadine at the earliest time point ( $3 \mathrm{~min}$ postchallenge). Only alcaftadine provided significant relief in chemosis at 16 and $24 \mathrm{~h}$ post-instillation. ${ }^{[13]}$ Alcaftadine prevented a decrease in expression of the junctional protein, ZO-1, which is caused by allergan challenge. In addition, animals treated with alcaftadine showed significantly lower conjunctival eosinophil infiltration ${ }^{[16]}$ In a comparative study involving $1.5 \%$ bepotastine besilate and $0.2 \%$ olopatadine and bepotastine showed better relief of ocular allergy symptoms and relief of runny nose. They found that a higher percentage of patients preferred bepotastine over olopatadine for treatment. ${ }^{[15]}$ Clinical trials, thus, proved efficacy of all three medications for relief of symptoms of allergic conjunctivitis but found differences between medications in one or the other parameters. In our study, all the three medications faired equally well in control of allergic symptoms, with no statistically significant difference between them.

olopatadine $0.2 \%$, and bepotastine $1.5 \%$ Alcaftadine $0.25 \%$, eyedrops have been proved to be safe and well-tolerated topical medication for allergic conjunctivitis.[17-20] These have been shown to have mild transient side-effects and are food and drug administration (FDA) approved. Our study resonated the same, and the medications were found to be safe, with minimal transient side effects of burning sensation noticed by a few patients (more in group 3 ).

Most patients responded to treatment and were willing to continue the eyedrop, if indicated. Efficacy of these antiallergic medications over placebo has been proved in

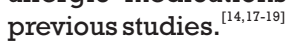

An additional part of our study was an double blind so there was masked observer for evaluation of signs of allergic conjunctivitis.. This hints toward the benefit of these medications for symptomatic relief alone in cases of allergic conjunctivitis.

There were some limitations to this study like small sample size, absence of cases of severe allergic conjunctivitis , effect of drug on signs of severe allergic conjunctivitis not taking consideration of avoidance of allergen like ciggarate smoke, small duration study (lmonth only ) To find out efficacy on long run requires further verification through clinical trials.

Moreover, as this was a focused study and we conduct this interventional clinical trial as randomized double blind and evaluation of each case at regular intervals for 1 month and found similar efficacy.

\section{Conclusion}

We concluded a similar efficacy of three medications in relieving symptoms

\section{Patient consent}

Written informed consent was taken from every patient included in the study

\section{Financial support and sponsorship}

Nil

\section{Conflicts of interest}

There are no conflicts of interest.

\section{REFERENCES}

1. Bonini S, Bonini S, Lambiase A, Marchi S, Pasqualetti P, Zuccaro O, et al. Vernal keratoconjunctivitis revisited: a case series of 195 patients with long-term followup. Ophthalmology.2000.Jun;107(6):1157-63.

2. So RA, Mufti A. Vernal Keratoconjunctivitis in Kashmir: A temperate zone. International ophthalmology.2016.Dec;36(6):875-879.Epub 2016 Mar 10.
3. Barbee RA, Kaltenborn W, Lebowitz MD, Burrows B. Longitudinal changes in allergen skin test reactivity in a community population sample.J Allergy Clin Immunol. 1987;79:16-24.

4. Verlato G, Corsico A, Villani S et al. Is the prevalence of adult asthma and allergic rhinitis still increasing. Results of an Italian study. J Allergy Clin Immunol. 2003;111:1232-1238.

4. Leonardi S, del Giudice Miraglia M, La Rosa M, Bellanti JA. Atopic disease, immune system, and the environment. Allergy Asthma Proc. 2007;28(4):410-417.10.2500/aap.2007.28.2954

5. Friedlander MH. Ocular Allergy. Curr Opin Allergy Clin Immunol. 2011;11(5):477-482.doi: 10.1097/ACI.0b013e32834a9652.

6. Saboo US, Jain M, Reddy JC, Sangwan VS. Demographic and clinical prole of vernal keratoconjunctivitis at a tertiary eye care center in India. Indian journal of ophthalmology. 2013.Sep;61(9):486-9

7. Ehlers WH, Donshik PC. Allergic ocular disorders: a spectrum of diseases. The CLAO journal: official publication of the Contact Lens Association of Ophthalmologists, Inc. 1992.Apr;18(2):117-24

8. Ishani Dudejal, Kaustubh Sane2 et al Observer-masked trial comparing efficacy of topical olopatadine $(0.1 \%)$, bepotastine $(1.5 \%)$, and alcaftadine $(0.25 \%)$ in mild to moderate allergic conjunctivitis

9. . Sánchez MC, Fernández Parra B, Matheu V, Navarro A, Ibáñez MD, Dávila I Dordal MT, Lluch Bernal M, Rondón C, Montoro J, Antón E, Colás C, Valero A (SEAIC Rhinoconjunctivitis Committee 2010). Allergic Conjunctivitis. J Investig Allergol Clin Immunol. 201 1;21 Suppl 2:1-19

10. Dell SJ, Shulman DG, Lowry GM, Howes J. A controlled evaluation of the efficacy and safety of loteprednoletabonate in the prophylactic treatment of seasonal allergic conjunctivitis. Loteprednol Allergic Conjunctivitis Study Group. Am JOphthalmol 1997;123:791-7

11. Dell SJ, Lowry GM, Northcutt JA, Howes J, Novack GD, Hart K.A randomized, double-masked, placebo-controlled parallel study of $0.2 \%$ loteprednoletabonate in patients with seasonal allergic conjunctivitis. J Allergy Clin Immunol 1998;102:251-5.

12. Mishra GP, Tamboli V, Jawla J, Mitra AK. Recent patents and emerging therapeutics in the treatment of allergic conjunctivitis. Recent Pat Inflamm Allergy Drug Discov 201 1;5:26-36

13. Ackerman S, D'Ambrosio FJr, Greiner JV, Villanueva L, Ciolino JB, Hollander DA. A multicenter evaluation of the efficacy and duration of action of alcaftadine $0.25 \%$ and olopatadine $0.2 \%$ in the conjunctival allergen challenge model.J Asthma Allergy 2013;6:43-52.

14. McLaurin EB, Marsico NP, Ciolino JB, Villanueva L, Williams JM, Hollander DA. Alcaftadine $0.25 \%$ versus olopatadine $0.2 \%$ in prevention of ocular itching in allergic conjunctivitis.J Allergy ClinImmunol 2014;133:AB278.

15. McCabe CF, McCabe SE. Comparative efficacy of bepotastinebesilate $1.5 \%$ ophthalmic solution versus olopatadine hydrochloride $0.2 \%$ ophthalmic solution evaluated by patient preference. Clin Ophthalmol 2012;6:1731-8.

16. Greiner JV, Edwards-Swanson K, Ingerman A. Evaluation of alcaftadine $0.25 \%$ ophthalmic solution in acute allergic conjunctivitis at 15 minutes and 16 hours after instillation versus placebo and olopatadine $0.1 \%$. Clin Ophthalmol 2011;5:87-93.

17. McLaurin EB, Marsico NP, Ackerman SL, Ciolino JB, Williams JM, Villanueva L, et al. Ocular itch relief with alcaftadine $0.25 \%$ versus olopatadine $0.2 \%$ in allergic conjunctivitis: Pooled analysis of two multicenter randomized clinical trials. Adv Ther 2014;31:1059-71.

18. Bergmann MT,Williams JI, Gomes PJ.Treatment of allergic conjunctivitis with bepotastinebesilate ophthalmic solution $1.5 \%$. Clin Ophthalmol 2014;8:1495-505.

19. Ackerman S, D'Ambrosio FJr, Greiner JV,Villanueva L, Ciolino JB, Hollander DA. A multicenter evaluation of the efficacy and duration of action of alcaftadine $0.25 \%$ and olopatadine $0.2 \%$ in the conjunctival allergen challenge model.J Asthma Allergy 2013;6:43-52.

20. Ono SJ, Lane $\mathrm{K}$. Comparison of effects of alcaftadine and olopatadine on conjunctival epithelium and eosinophil recruitment in a murine model of allergic conjunctivitis. Drug Des DevelTher 201 1;5:77-84

21. McCabe CF, McCabe SE. Comparative efficacy of bepotastinebesilate $1.5 \%$ ophthalmic solution versus olopatadine hydrochloride $0.2 \%$ ophthalmic solution evaluated by patient preference. Clin Ophthalmol 2012;6:1731-8 